\title{
Cytotoxic Effects of Lysimachia ramosa Wall. Ex Duby (Primulaceae) on Swiss Albino Mice
}

\author{
Bishnupada Roy* and Paulomi Dey \\ Department of Zoology, North-Eastern Hill University, Shillong, India
}

\begin{abstract}
Lysimachia ramosa is a traditional medicinal plant, consumed by different tribes of northeast India to cure intestinal helminth infections. In order to measure the toxic effects of the plant on its consumer, if any, the present in vivo study was carried out on mice using sub-lethal doses of crude ethanol extract viz. 100 and $200 \mathrm{mg} / \mathrm{kg}$ body weight for 14 days. Surface topographical and ultrastructural observations on liver, kidney and intestine of treated mice revealed marked deformation and destruction accompanied by quantitative changes in liver and kidney markers like aspartate aminotransferase, alanine aminotransferase and creatinine in comparison to the control mice. The results showed that consumption of crude plant extract at a dose $100 \mathrm{mg}$ and above per $\mathrm{kg}$ body weight continuously for long time may cause toxic effects to its consumer.
\end{abstract}

Keywords: Lysimachia ramosa; Albino mice; Toxicity; Green medicine; Phytoproducts

\section{Introduction}

The concept of "Green medicine" is based on the fact that phytoproducts are believed to be safe, easily available, cheap and more dependable compared to the highly expensive synthetic drugs, most of which have undesired effects on its consumers [1]. However, many herbal medicines could be potentially injurious to human health, because large numbers of these products exert toxic effects on haematological parameters, liver, kidney, heart, brain, intestine and reproductive tissues of its consumers [2-4]. In spite of undesired side effects of traditional treatment using natural products, demands for plant products are gradually increasing both in developing and developed countries for treatment of different diseases or as food supplements [5]. Phyto-products related market in a developing country like India is expanding at a rate of $20 \%$ per year, where $50 \%$ of total floras are known to have medicinal potential and about $70 \%$ population consume traditional medicinal plants to cure different diseases [6-8].

Lysimachia ramosa Wall. Ex Duby belong to the family Primulaceae is a shrub bearing yellow flower, grow in damp condition. Aqueous extract of its leaves are widely used by different tribes in northeast India to cure intestinal helminthic infection. Preliminary investigation carried out on different helminthic parasites revealed that alcoholic crude extract of the plant indeed have anthelmintic properties, as it paralyses and kills trematode, cestode and nematode within 2.22, 4.51 and 26.45 $\mathrm{h}$ respectively, when exposed to $50 \mathrm{mg}$ of the crude plant extract per $\mathrm{ml}$ of phosphate buffer saline [9]. Thus, the result obtained through the in vitro experiments clearly indicates that the crude alcoholic extract of $L$. ramosa justifies its use in traditional healing system. However, no literature is available about the extent of toxic effect of the plant, if any on its consumer. Therefore, an in vivo experiment was carried out to evaluate the cytotoxic effect of the plant in Swiss albino mice taking blood, intestine, liver and kidney as target tissues.

\section{Materials and Methods}

\section{Chemicals}

All the chemicals and reagents used were obtained from Himedia, India (L-aspartic acid, Alanine, a-ketoglutarate, 2,4 dinitrophenylhydrazine, Pyruvate, Sodium hydroxide, Potassium chloride, Sodium chloride, Di-sodium hydrogen phosphate, Potassium dihydrogen phosphate, Picric acid, EDTA disodium salt, Creatinine), Jebsen \& Jessen GnbH \& Co., Germany (Ethanol, Dimethyl sulphoxide) and SRL, India (Chloroform).

\section{Preparation of plant extract}

Plants (Lysimachia ramosa) were procured from different parts of Jaintia Hills of Meghalaya, India. Leaves were separated from the stem, thoroughly washed with deionized water and dried in shade. The dried leaves were crushed into fine powder with the help of electric grinder and then refluxed with ethanol $(100 \mathrm{~g} / \mathrm{l})$ for $6 \mathrm{~h}$ at $60^{\circ} \mathrm{C}$. The solution obtained was filtered through Whatman filter paper (No. 1) and then evaporated to complete dryness at $50^{\circ} \mathrm{C}$. The crude extract was obtained as powder material, which was kept at $4^{\circ} \mathrm{C}$ until further use. $2 \mathrm{~h}$ prior to experiment, different concentrations of the extract viz. 100 $\mathrm{mg}$ and $200 \mathrm{mg} / \mathrm{kg}$ body weight were prepared by dissolving the extract in $0.9 \%$ Phosphate Buffer Saline (PBS, pH 7-7.3) having 0.1\% Dimethyl Sulfoxide (DMSO). In traditional use, different tribes consume 50-75 $\mathrm{mg} / \mathrm{kg}$ body weight, twice a day, continuously for 15 days.

\section{Animals and treatment}

Experiment on animals was performed in accordance with the Animal Ethics Committee's guidelines for laboratory animal use and care. A total of 18 adult Swiss albino mice weighing between 22-28 g were purchased from Pasture Institute, Shillong, India. They were kept in metal cages in the animal house having uniform temperature of $25^{\circ} \mathrm{C}$ with $12 \mathrm{~h}$ light and $12 \mathrm{~h}$ dark periodicity. The animals were fed up with standard feed and water ad libitum. All the mice were acclimatized for

*Corresponding author: Bishnupada Roy, Department of Zoology, NorthEastern Hill University, Shillong 793 022, India, Tel: 00913642722331; E-mail: bishnuroy12@rediffmail.com

Received November 01, 2016; Accepted November 25, 2016; Published November 29, 2016

Citation: Roy B, Dey P (2016) Cytotoxic Effects of Lysimachia ramosa Wall. Ex Duby (Primulaceae) on Swiss Albino Mice. J Pharmacogn Nat Prod 2: 126. doi: 10.4172/2472-0992.1000126

Copyright: @ 2016 Roy B, et al. This is an open-access article distributed under the terms of the Creative Commons Attribution License, which permits unrestricted use, distribution, and reproduction in any medium, provided the original author and source are credited. 
two weeks before starting the experiment. A total of six mice of either sex ( 3 males and 3 females) were selected for each set of experiment. The crude ethanol extract ( $100 \mathrm{mg}$ and $200 \mathrm{mg} / \mathrm{kg}$ body weight) of the plant were administered orally once every day with the help of gastric feeding tube. Control animals were fed up with PBS having DMSO only. Administration of crude extract and vehicle (DMSO) continued for 14 days, followed by starvation of mice for overnight. On day $15^{\text {th }}$, weight of each mouse was recorded, chloroform anesthetized and sacrificed for collection of blood, intestine, liver and kidney.

\section{Biochemical assay}

To determine biochemical indices for liver function test i.e., Aspartate Aminotransferase (AST) and Alanine Transaminase (ALT), collected blood was kept at room temperature for $35 \mathrm{~min}$, centrifuged at $3000 \mathrm{rpm}$ for $15 \mathrm{~min}$ at $4^{\circ} \mathrm{C}$ and the serum was isolated to determine activity of AST and ALT following colorimetric method as described by Reitman and Frankel [10]. The serum level of Creatinine (sCr) was determined following Jaffe' method. Briefly, to $1 \mathrm{ml}$ of working reagent (pricric acid $(9 \mathrm{~mm} / \mathrm{l})+\mathrm{NaOH}(400 \mathrm{~mm} / \mathrm{l})+$ EDTA $12.5 \mathrm{~mm} / \mathrm{l})$ was mixed with $100 \mu \mathrm{l}$ of blood serum, whereas, for standard $100 \mu \mathrm{l}$ of 2 $\mathrm{mg} / \mathrm{dl}$ creatinine was added in the working reagent. After $30 \mathrm{~s}$ initial Absorbance (Al) was recorded at $492 \mathrm{~nm}$. The final Absorbance (A2) was recorded $90 \mathrm{~s}$ at $37^{\circ} \mathrm{C}$. The concentration of creatinine was measured in $\mathrm{mg} / \mathrm{dl}$ using the formula:

$$
\text { Creatinine }(m g / d l)=\frac{\Delta \text { Abs of sample }}{\Delta \text { Abs of } s \tan \text { dard }} \times \text { Conc.of Std. }(m g / d l)
$$

\section{Scanning and transmission electron microscopy}

Tissues (liver, kidney, and intestine) of control and plant extractsexposed mice were fixed in modified Karnovsky's fixative, post-fixed in $1 \% \mathrm{OsO}_{4}$ buffered with $0.2 \mathrm{M}$ sodium cacodylate for $4 \mathrm{~h}$, dehydrated through graded series of acetone, and embedded in araldite. Ultrathin sections were stained with uranyl acetate followed by lead citrate and were viewed under a transmission electron microscope (JEOLJEM 2100). For observation of surface alterations, scanning electron microscopy was carried out through fixation of tissues in neutral buffer formalin, followed by dehydration in acetone grades and air drying in tetramethylsilane following Dey et al. [11] modified by Roy and Tandon [12]. The gold coated specimens were viewed under a scanning electron microscope.

\section{Results}

\section{Observations on body weight}

Weight of control and of L. ramosa crude extract treated mice is presented in Figure 1. A decrease in weight of mice was observed with an increase in treatment dose of the extract.

\section{Observations on biochemical markers}

Figures 2-4 represent the extent of ALT and AST alterations in the plant extract treated mice compared to the control. Both ALT and AST showed significant $(P \leq 0.001)$ increase in serum concentration when exposed to $100 \mathrm{mg}$ and $200 \mathrm{mg} / \mathrm{kg}$ body weight. Serum level of creatinine was also found to be increased significantly $(P \leq 0.01)$ at both the doses.

\section{Observations on ultrastructure}

Scanning electron microscopic observations on liver of control mice showed normal sinusoidal lumen lined with epithelium, intact parenchyma cells and fenestrae (Figure 5A). Lysimachia ramosa

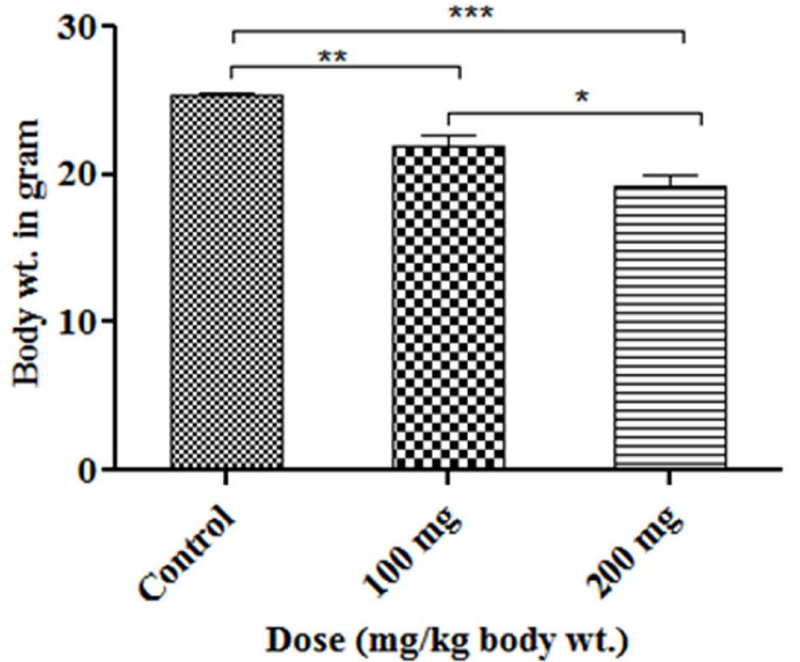

Figure 1: Decreased trend in the body weight of albino mice administered with two different doses of Lysimachia ramosa crude extract. Values are significant at ${ }^{*} \mathrm{P} \leq 0.05 ;{ }^{* *} \mathrm{P} \leq 0.01 ;{ }^{* * *} \mathrm{P} \leq 0.001(\mathrm{n}=6)$.

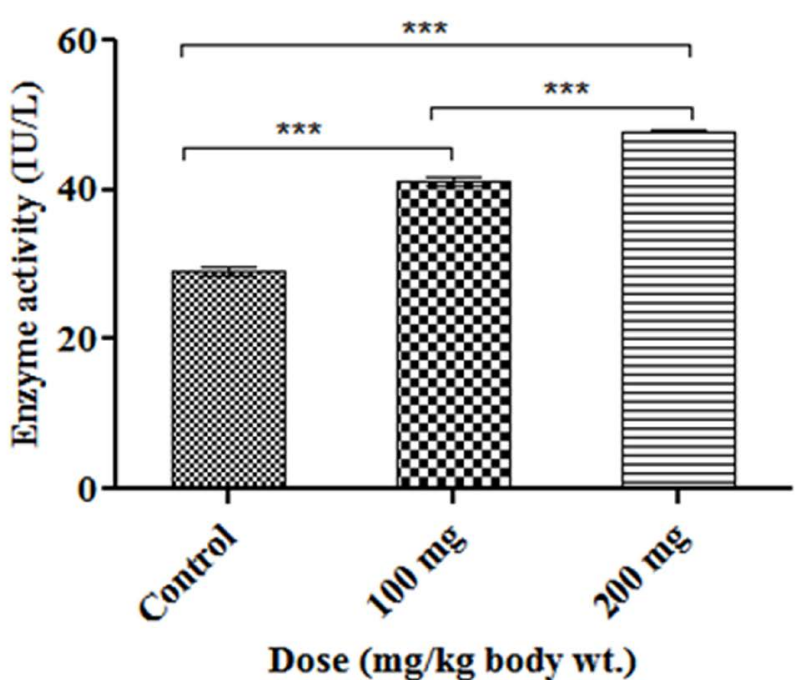

Figure 2: Effect of ethanol extract of Lysimachia ramosa on liver enzyme alanine transaminase of Swiss albino mice. " Values are significant at $P \leq 0.001 ;(n=6)$.

treated liver surface showed severe damage in endothelial lining and dilation of fenestrae (Figure 5B). Control lumen of intestine revealed regular arrangement of microvilli with intact surface, however, the plant extract treated intestinal surface showed severe deformation and disruption leading to total collapse of microvilli (Figures 6A and 6B). Transmission electron microscopic observations on lumen of intestine showed regular lining of microvilli having uniform epithelial layer, compact cytoplasm, normal mitochondria and other cell organelles in the control mice (Figure 7A). Mice exposed to ethanol extract (200 mg/ $\mathrm{kg}$ body weight) of L. ramosa showed complete destruction of cellular structure, swelling of microvilli, deformation of nuclear membrane, condensation of chromatin granule and nucleolus (Figure 7B). Regular shaped cells with defined cell membrane, compact cytoplasm, distinct nuclear membrane and mitochondria having mitochondrial cristae 


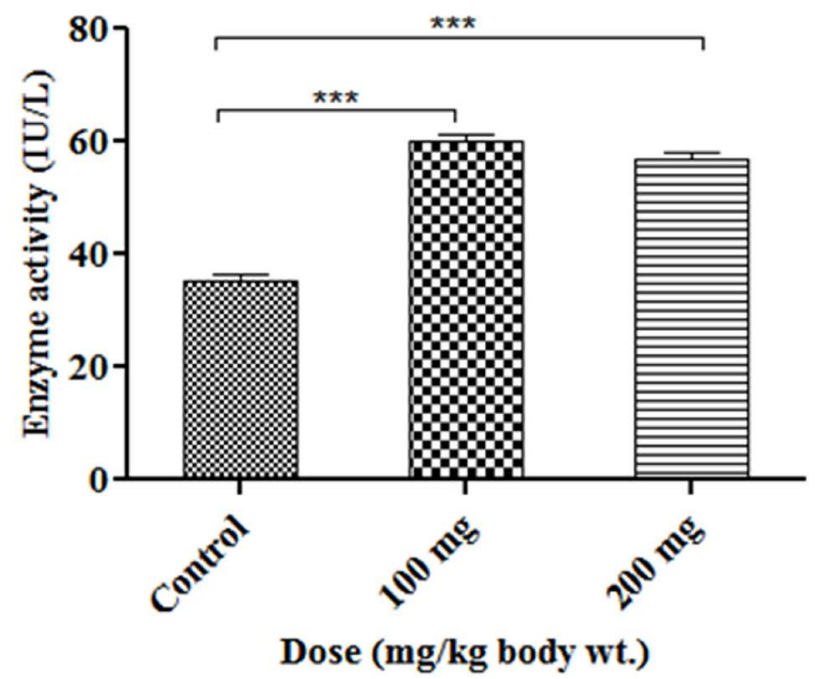

Figure 3: Effect of ethanol extract of Lysimachia ramosa on liver enzyme aspartate amino transaminase of Swiss albino mice. " Values are significant at $P \leq 0.001 ;(n=6)$.

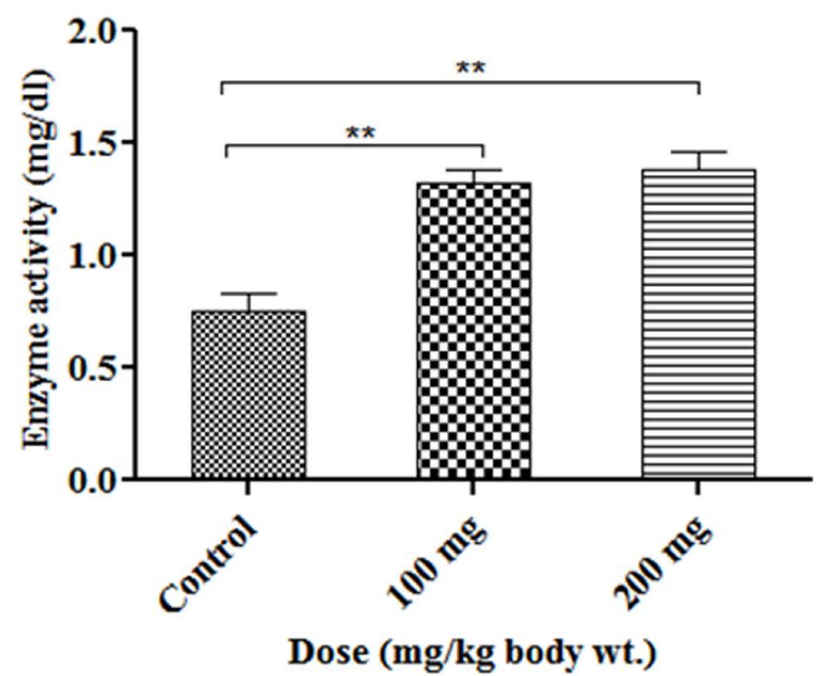

Figure 4: Effect of ethanol extract of Lysimachia ramosa on serum creatinine of Swiss albino mice. ${ }^{* *}$ Values are significant at $P \leq 0.01 ;(n=6)$.

were observed in the control cells (Figure 7C). However, complete disintegration of cell organelle, discontinuous nuclear membrane, swelling of mitochondria with no distinct cristae was evident in the extract treated cells (Figure 7D). Normal architecture of epithelial cells of proximal convoluted tubule, mitochondria and other cell organelle was evident in the kidney (Figure 7E). However, plant extract treated kidney showed vacuolated nucleus and vacuolated mitochondria having disintegrated cristae (Figure 7F).

\section{Discussion}

Decrease in the weight of drug exposed animals is considered as one of the important criteria to evaluate toxic effects of drugs on health. The results of our present study showed a significant decrease in the body weight of mice when treated with ethanol extract of $L$. ramosa compared to the control. A similar type of loss in body weight was also observed in rats exposed to crude methanol extract of two traditional medicinal plants Carex baccans and Potentilla fulgens [13].

Of the several functions performed by liver and kidney, elimination of toxic substances and waste products is regarded as vital processes. Thus malfunctioning of these organs due to any form of damage leads to leakage of enzymes in to the blood circulation. ALT and AST are two marker enzymes, used to assess the extent of liver damage. Thus, an elevated level of these two enzymes observed in the serum of mice exposed to ethanolic extract of $L$. ramosa indicates the hepatotoxic potential of the plant [14]. A significant increase in serum creatinine as observed in our present study also indicates the extent of kidney damage caused by the phytoproduct. This kind of damage is generally caused by toxic chemicals and muscle injury [15]. Similar to the present observations, an increase in AST and ALT in rodents due to exposure to different concentration of crude extract of Punnica granatum (fruit), Carex baccans (root peel) and Potentilla fulgens (root tuber peel) was reported $[13,16]$. According to Alexis et al. a raised level of AST and ALT as observed in the rat exposed to crude extract of Punica granatum could be due to de novo synthesis of the enzyme molecules or an adaptation by the liver to the assault from the phytoproduct [16].

The mice exposed to extract of L. ramosa showed alterations in the surface micro-topography as well as cellular structure in the liver of the animal in the form of destruction of sinusoidal vascular bed and
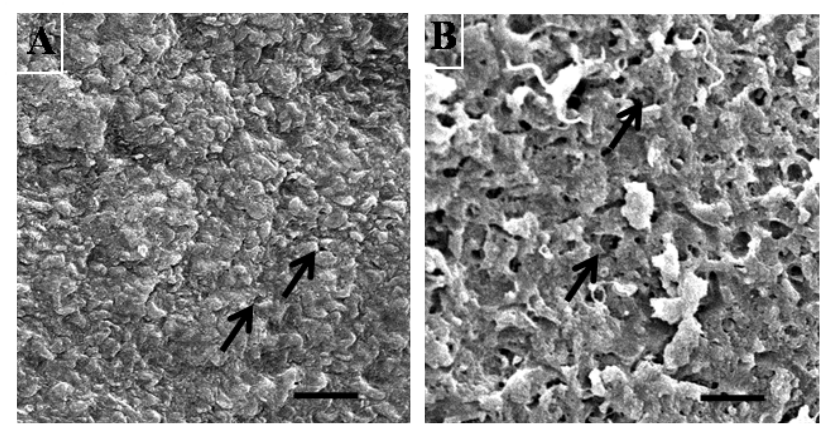

Figure 5: Scanning electron micrographs of $(A)$ control and $(B)$ Lysimachia ramose extract administered liver of albino mice. (A) Surface topography of liver showing normal and intact parenchyma cells and the pores known as fenestrae (arrow). (B) Liver surface showing severe damage and disintegration of endothelial lining having increased number of deformed fenestrae $(F)$. All scale bars $=10 \mu \mathrm{m}$.
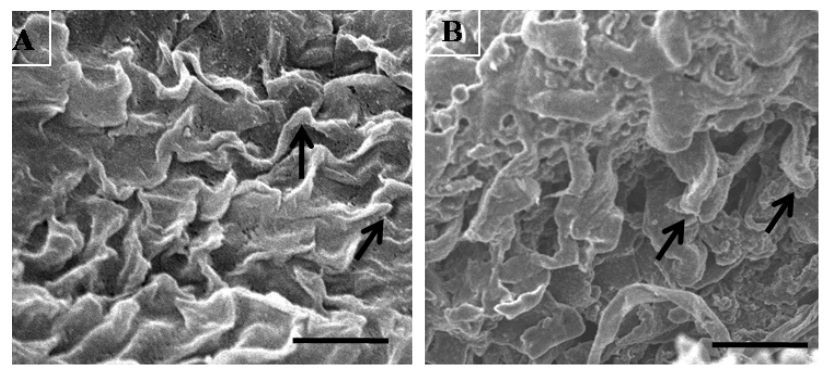

Figure 6: Scanning electron micrographs of $(A)$ control and (B) Lysimachia ramose extract exposed intestinal lumen of albino mice. (A) Control lumen showing normal intestinal epithelium with regular arrangement of microvilli (arrows) (B) Intestinal surface showing severe deformation and disruption of microvilli (arrows). All scale bars $=50 \mu \mathrm{m}$. 

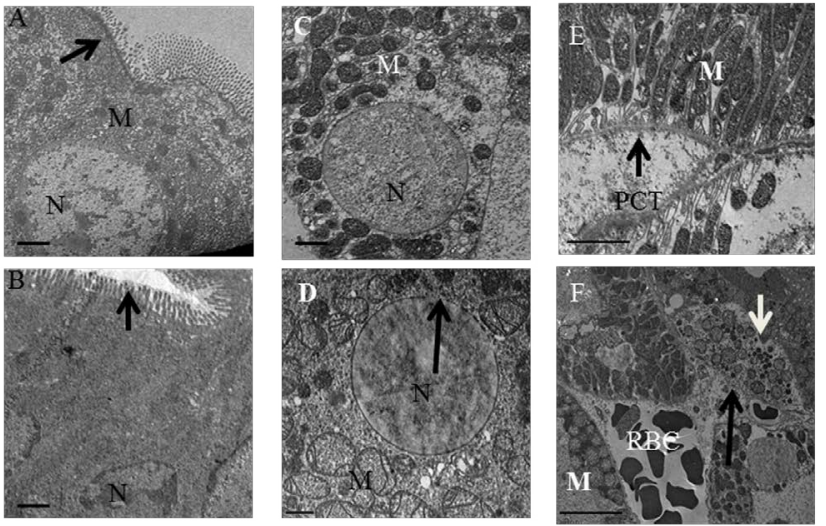

Figure 7: Transmission electron micrographs of intestine (A, B), liver (C,D) and kidney (E,F) of mice; (A) Transmission electron microscopic observations on the lumen of intestine showed regular lining of microvilli having uniform epithelia layer (arrow), compact cytoplasm, normal mitochondria (M), well defined nucleus $(\mathrm{N})$ and other cell organelles. (B) Lysimachia ramosa $(200 \mathrm{mg} / \mathrm{kg}$ body wt.) administered intestine showing disrupted intestinal epithelium, deformed nucleus $(\mathrm{N})$ and no distinguished cell organelles. (C) Control Liver showing normal plasma membrane, nucleus (N) and mitochondria (M). (D) L. ramosa (200 mg/kg body wt.) exposed liver showing discontinuous nuclear membrane (arrow), swollen mitochondria (M) with disintegrated cristae. (E) Control kidney showing intact proximal convoluted tubule (PCT), normal elongated mitochondria $(\mathrm{M})$ with normal patterns of cristae and mitochondrial membrane. (F) L. ramosa $(200 \mathrm{mg} / \mathrm{kg}$ body wt.) treated kidney showing breakage in the proximal convoluted tubule (arrow), vacuolated mitochondria (M), increased number of lysosomes (white arrow) and disrupted red blood corpuscles (RBC) (Figures: A,B,C,D: Scale bar $=2 \mu \mathrm{m}$; Figures: $E$ and F: scale bar $=5 \mu \mathrm{m}$ ).

parenchyma cells. Thus, it appears that the plant extract had affected the endothelial lining directly, resulting in loss of integrity of the liver architecture [13]. Change in structure of hepatocytes was also observed in liver of mouse exposed to the chemical fipronil, an active ingredient of acaricide Frontline (R) [17]. McGregor and others also observed damage and death of hepatocytes in humans treated with over-doses of paracetamol [18].

An increase in serum creatinine level accompanied by disruption of convoluted tube, renal epithelial cells and vacuolization of mitochondria as observed in the kidney of mice treated with L. ramosa indicate the extent of disturbed kidney function. Similar type of damaged kidney was also observed in mice treated with arsenic trioxide sub-chronically at a dose $4 \mathrm{mg}$ for 60 days [19]. Kang and associates showed that 4-hydroxy-2-nanonal which is present in remarkably high amount in food products, increase kidney weight at a dose of $12.5 \mathrm{mg} /$ $\mathrm{kg} /$ day for 28 days and damage the kidney through accumulation of hyaline bodies in the renal tubule leading to dehydration of tubular epithelium [20].

Intestinal epithelium acts as a selective filter facilitating the uptake of dietary nutrients from the lumen; however, it also acts as a barrier to prevent entry of harmful substances such as foreign antigens, toxins and microorganisms. Microvilli of intestinal lumen increase the surface area for absorption of food, mineral, water and secretion of different chemicals/enzymes. In the present study mice exposed to the phyto-product exhibit extensive deformation and destruction of lumen of intestine leading to malfunction of the organ. Similar to the present observation, non-steroidal anti-inflammatory drugs like aspirin, ibuprofen, naproxen etc. revealed to inhibit production of protective gastric mucosal prostaglandins resulting in development of gastrointestinal erosions and ulceration through local and systematic interaction with prostaglandin synthesis [21-23]. At present, active principle(s) of $L$. ramosa responsible for its pharmacological activities is not known; however, preliminary screening carried out revealed the presence of phenols, tannins, terpenoids and flavonoids. Active components recovered from other species of Lysimachia are flavones, triterpenoid, saponins and organic acids [24]. Triterpenoid saponins are known to have cytotoxic activity against skin fibroblasts and tumour cells [25].

It is concluded that the ethanol extract of $L$. ramosa has caused significant alterations in structure and function of liver, kidney and intestine at a dose $100 \mathrm{mg} / \mathrm{kg}$ body weight an above, when consumed continuously for long time. However, to know the mechanism of toxic action, it is pre-requisite to identify the active compound of the plant responsible for toxicity.

\section{Acknowledgement}

This study was supported by a research grant from the University Grants Commission, Govt. of India, New Delhi. Infrastructural support provided by the Department of Zoology and Sophisticated Analytical Instrument Facility, NorthEastern Hill University, Shillong, India are gratefully acknowledged.

\section{References}

1. Parekh J, Chanda S (2006) In vitro antimicrobial activities of extracts of Laenaea procumbens Roxb. (Labiateae), Vitis vinifera L. (Vitaceae) and Cyperus rotundus L. (Cyperaceae). Afr J Biomed Res 9: 89-93.

2. Ernst E (2003) Serious psychiatric and neurological adverse effects of herba medicines-a systemic review. Acta Psychiatr Scand 108: 83-91.

3. Lima CF, Fernandes-Ferreira M, Fereira-Wilson C (2007) Drinking of Salvia officinalis tea increases CCl4-induced hepatotoxicity in mice. Food Chem Toxicol 45: 456-464

4. Giri BR, Roy B (2013) Nephrotoxic potential of Carex baccans (Family: Cyperaceae): a light and electron microscopic studies. J Toxicol Health 103 : 244-251

5. Li L, Henry GE, Seeram NP (2009) Identification and Bioactivities of Resveratrol Oligomers and Flavonoids from Carex folliculate Seeds. J Agric Food Chem 57: 7282-7287.

6. Rates SKM (2001) Plants as source of drugs. Toxicon 39: 603-613.

7. Srivastava R (2000) Studying the information needs of medicinal plant stakeholders in Europe. Traffic Dispatches 15: 5

8. Sharma P, Sharma CM (2008) In vitro regeneration of rare medicinally potent plant of estern Himalaya hotspot. In: Kumar A, Sopory SK (eds.) Recent Advances in plant Biotechnology and its Applications. IK International publication, New Delhi.

9. Challam M, Roy B, Tandon V (2010) Effect of Lysimachia ramosa (Primulaceae) on helminth parasites: Motility, mortality and scanning electron microscopic observations on surface topography. Vet Par 214: 214-218.

10. Reitman S, Frankel AS (1957) A colorimetric method for determination of serum glutamic oxaloacetic and glutamic pyruvic transaminase. Am J Clin Pathol 28 $56-63$.

11. Dey S, Basubaul TS, Roy B, Dey D (1989) A new rapid method of air drying for scanning electron microscopy using tetramethyl silane. J Microsc 6: 259-261.

12. Roy B, Tandon V (1991) Usefulness of tetramethyl silane in the preparation of helminth parasites for scanning electron microscopy. Riv Parasitol 8: 405-413.

13. Roy B, Giri BR, Chetia M, Swargiary A (2012) Ultrstructurl and biochemical alterations in rats exposed to crude extract of Carex baccans and Potentilla fulgens. Microsc Microanal 18: 1067-1076.

14. Orisakwe OE, Hussaini DC, Afonne OJ (2003) Testicular effects of sub-chronic administration of Hibiscus sabdariffa calyx aqueous extract in rats. Reprod Toxicol 18: 295-298.

15. Hashemi SJ, Hajiani E, Sardabi EH (2009) A placebo-controlled trial of silymarin in patients with nonalcoholic fatty liver disease. Hepat Mon 9: 265-270.

16. Alexis V, Adyary F, Blanca RP, Maria EM, Bienvenido G, et al. (2003) Studies on the toxicity of Punica granatum L. (Punicaceae) whole fruit extracts. J Ethnopharmacol 89: 295-300. 
Citation: Roy B, Dey P (2016) Cytotoxic Effects of Lysimachia ramosa Wall. Ex Duby (Primulaceae) on Swiss Albino Mice. J Pharmacogn Nat Prod 2: 126. doi: 10.4172/2472-0992.1000126

Page 5 of 5

17. Ferreira M, De Oliveira PR, Denardise SE, Bechara GH, Mathias MI (2012) Action of the chemical agent fipronil (active ingredient of acaricide Frontline) on the liver of mice: An ultrastructural analysis. Microsc Res Techniq 75: 197-205.

18. Mc Gregor AH, More LJ, Simpson KJ, Harrison DJ (2003) Liver-death and regeneration in paracetamol toxicity. Human Exp Toxicol 22: 221-227.

19. Li L, Henry GE, Seeram NP (2009) Identification and bioactivities of resveratrol oligomers and flavonoids from Carex folliculata seeds. J Agric Food Chem 57: 7282-7287.

20. Kang SC, Kim HW, Kim KB, Kwack SJ, Ahn IY, et al. (2011) Hepatotoxicity and nephrotoxicity Produced by 4-Hydoxy-2-Nonenal (4-HNE) Following 4-week Oral Administration to Sprague-Dawley Rats. J Toxic Env Hlth 74: 779-789.
21. Halter $F$ (1988) Mechanism of gastrointestinal toxicity of NSAIDs. Scand $J$ Rheumatol Suppl 73: 16-21.

22. Bjarnason I, Thjodleifsson B (1999) Gastrointestinal toxicity of non-steroida anti-inflammatory drugs: the effect of nimesulide compared with naproxen on the human gastrointestinal tract. Rheumatology 38: 24-32.

23. Cyer B (2000) NSAID gastrointestinal toxicity. Curr Opin Gastroenterol 16: 495-502.

24. Liang B, Tiang J, Xu L, Yang S (2006) Triterpenoid saponins from Lysimachia davurica. Chem Pharm Bull 54: 1380-1383.

25. Galanty A, Michalik M, Sedek L, Podolak I (2008) The influence of LTS-4 a saponoside from Lysimachia thyrsiflora L., on human skin fibroblasts and human melanoma cells. Cell Mol Biol Lett 13: 585-598. 